\title{
Monitoring risk behaviour in adolescent pupils regarding consumption of psychoactive substances
}

\author{
Paulina Wojtyła-Buciora',2, Aneta Klimberg ${ }^{3}$, Lucyna Kapka-Skrzypczak ${ }^{4,5}$, Jarosław Diatczyk ${ }^{6}$, \\ Monika Urbaniak7, Ewa Ulatowska-Szostak ${ }^{3}$, Tomasz Bołdowski ${ }^{8}$, Andrzej Wojtyła², \\ Jerzy T Marcinkowski ${ }^{3}$ \\ 1 Department of Physiology, University of Medical Sciences, Poznan, Poland \\ ${ }^{2}$ Higher Vocational State School, Kalisz, Poland \\ ${ }^{3}$ Department of Hygiene, Poznan University of Medical Sciences, Poznan, Poland \\ ${ }^{4}$ Department of Molecular Biology and Translational Research, Institute of Rural Health, Lublin, Poland \\ ${ }^{5}$ Chair of Medical Biology and Translational Research Faculty of Medicine, University of Information Technology and \\ Management, Rzeszow, Poland \\ ${ }^{6}$ Institute of Electrical Engineering and Electrotechnologies, Faculty of Electrical Engineering and Computer Science \\ Lublin University of Technology, Poland \\ ${ }^{7}$ Chair and Department of Facility Management Organizations in Health Care, University of Medical Sciences, Poznan, \\ Poland \\ ${ }^{8}$ Department of Emergency Medicine, Poznan University of Medical Sciences, Poznan, Poland
}

Wojtyła-Buciora P, Klimberg A, Kapka-Skrzypczak L, Diatczyk J, Urbaniak M, Ulatowska-Szostak E, Bołdowski T, Wojtyła A, Marcinkowski JT. Monitoring risk behaviour in adolescent pupils regarding consumption of psychoactive substances. Ann Agric Environ Med. $2017 ; 24(2): 350-355$. https://doi.org/10.26444/aaem/74449

\begin{abstract}
Introduction. Taking psychoactive substances constitutes a significant problem for Public Health, particularly in preventing drug abuse and addiction.

Objectives. To estimate the amount and incidence of drug consumption in middle and high school pupils, including the circumstances in which drug taking first started, and to determine pupils' knowledge about the consequences of taking psychoactive substances and designer drugs (DDs).

Materials and methods. A randomised study was conducted throughout Poland on 9,360 pupils attending middle school (junior high school) in 2009 and 7,971 pupils from middle and high school pupils in 2011. The survey consisted of a questionnaire devised by the Chief Sanitary Inspectorate (GIS) and the replies obtained were subject to the relevant statistical analyses.

Results. Drug taking was found to have increased between 2009-2011, especially among those attending high school; proportionally rising from $4 \%-11 \%$. The numbers who had ever taken designer drugs were $3 \%$ for middle school pupils and $4 \%$ from high school.

Conclusions. 1) Adolescent drug consumption has increased, particularly in those of older age and in boys. 2) Despite the only brief interval for which designer drugs were legal, they have gained high popularity among the young. 3) Adolescents have insufficient knowledge about the dangers of using DDs. 4) Faced with the growing threat of a dynamic designer drug market, appropriate counter-measures in education and prevention are therefore necessary.
\end{abstract}

\section{Key words}

drugs/narcotics, designer drugs (DDs)/legal highs, adolescents/youth

\section{INTRODUCTION}

Drug addiction/abuse is one of the major problems confronting Public Health. Its complexity arises from the ever-decreasing age at which persons become addicted and their first contact with taking psychotropic substances. It is estimated that there are globally 185 million people taking illegal substances, constituting $3 \%$ of the total world population, of whom $5 \%$ are those aged 15 to 64 years [1]. In Poland, the prevalence of drug abuse is very diverse. It has been found that over $35 \%$ of adolescents have experienced taking drugs, most commonly marihuana; however, in some places this behaviour has not been observed at all [2]. Although the consequences of such behaviour can be devastating, knowledge of drug addiction

Addres for correspondence: Lucyna Kapka-Skrzypczak, Department of Molecular Biology and Translational Research, Institute of Rural Health, Lublin, Poland E-mail:lucynakapka@gmail.com

Received: 5 June 2014; accepted: 12 November 2014; first published on February 2017 and abusing other psychoactive substances is still limited.

A suitable definition is provided by the amended Act of 29 July 2005 on counteracting drug addiction, (JL 2012, item 124): The permanent or periodical taking of non-medicinal drugs, psychoactive or substitute substances from which an addiction might arise or may have arisen [3]. Drug addiction may include both illegal and legal substances, covering psychotropic medicinal substances, as well as those used for the purposes of being intoxicated. Such active substances, when banned by international law, are thus termed drugs (narcotics).

At the present time, designer drugs (DDs) undoubtedly constitute a large threat as they are inherently designed to provide an alternative to established drugs and other intoxicating substances, through mimicking their psychoactive effects [4]. DDs include a diverse range of substances and mixtures that can be obtained from plants and seeds, albeit the main thrust of this industry is to synthesise new compounds 
based on modifications to the molecular structures of already known psychoactive ones [5-7]. As reported by the European Monitoring Centre for Drugs and Drug Addiction (EMCDDA), DDs maybe differentiated into 'Herbal Highs' or 'Legal Highs' [8]. The deceptively sounding name 'Herbal Highs' suggest that such products are natural in origin, thereby implying that they are safer. However, they include substances that can be psychoactive which are usually synthetic, sometimes of plant origin, or partially synthetic. A significant part of this group consists of 1-benzylpiperazine (BZP), a substance with similar action to amphetamine [9-12]. The widespread dissemination of DDs as safe substances has resulted in adolescents not treating/regarding them as drugs of abuse or addiction and thus their consumption is ever increasing. In order to prevent this, many of the active DD substances have been placed on a banned list according to the 1st April 2011 amendment made to the Act concerning counteracting drug addiction, (JL No. 117 , item 124). Nevertheless, the problem continually exists, as de-legalised substances are constantly replaced with new ones of similar action, but which do not fulfil the criteria for their prohibition. The legal steps of continuously updating lists of banned substances is insufficient as this process is time consuming. Furthermore, it constitutes a type of attractive challenge or spur to manufacturers, stimulating them seek or synthesise new compounds as replacements for those being made illegal [13-16].

Constant monitoring of adolescent risky behaviour/lifestyle is therefore necessary regarding the use of psychoactive substances and the mechanisms involved. Gaining information on knowledge, beliefs and opinions on such behaviour can thus serve to formulate various and appropriate remedial actions targeted against this phenomenon.

\section{OBJECTIVES}

1. Estimating the amount and incidence (scale) of drug and DD use amongst middle and high school pupils in Poland.

2. Determining the most likely ages and circumstances that first contact with drugs is made by the aforementioned pupils.

3. Investigating the relationship between pupils' drug or DD-taking with their knowledge of the consequences of such action.

4. Comparing the scale of drug taking declared by pupils with those assessed by their parents.

\section{MATERIALS AND METHOD}

In 2009, a randomised pilot study was conducted in a local district of Poland where $n=1,100$ high school pupils, (679 girls and 320 boys), together with their parents, were surveyed. From had the questionnaire replies received, $n=999$ were correct from pupils and $n=667$ from their parents. Those rejected had less than $50 \%$ correct compliance. The questionnaire had been designed by GIS, based on a previous one used for the Global School-base Student Health Survey (GSHS). The survey was carried out by health education units of the State Sanitary Inspectorate (PIS). For the purposes of comparison, questions were directed to both pupils and parents in order to obtain more reliable results on the pro-healthy or unhealthy lifestyle behaviour of respondents. The pilot study was then used as a guideline for undertaking the main study, in the same year (2009), on 12,005 middle-school pupils, together with their parents. Of these, 9,360 pupils (4,961 boys and 4,399 girls) and 6,951 parents provided correct replies which lent themselves to subsequent statistical treatment.

This last study was repeated in 2011 on another group of randomised adolescents attending middle and high school so that a comparison and diagnosis of drug use could be made over the passage of time. From the total 10,083 subjects surveyed, 7971 (79\%) submitted correct questionnaires. These broke down into, respectively, 3,548 and 4,423 middle and high school pupils. Of the former, 1,742 and 1,806 were respectively girls and boys, while the latter comprised 2,275 girls and 2,148 boys. In 2011, the survey did not include parents because results from 2009 had demonstrated poor correlation between the replies by pupils and parents. The questionnaire was extended, however, to include issues important to adolescents, such as DDs. Questions were also more specifically targeted to the consumption of psychoactive substances than previously.

The survey had two randomisation steps, the first of which was for choosing the school and the second for selecting the school type (i.e. middle or high school). Clustered samples of pupils per type were also taken, where only those who had anonymously completed questionnaires were selected. When choosing the schools, the following criteria were taken into account: type, district and municipality. Pupils were randomly sampled from a schools' and institutions' base compiled by the Ministry of National Education on 30 September 2008. In the first stage, four types of schools were selected (i.e. middle school, comprehensive high school, specialist high school and technical school), followed by a randomised selection procedure using statistical Statistica and SPSS software programmes.

Hand-written data from the questionnaires were entered into a central data base by means of an integrated system of data gathering and imputing, allowing statistical analyses to be performed by the STATISTICA programme package. A Pearson $\chi 2$ (Chi-Squared) test was used to statistically determine whether variables were related, by testing the independence of $m \geq 2$ characteristics expressed as nominally scaled variables. The test was verified by calculating $\chi 2$ statistic values and comparing them with values pre-determined by the Null Hypothesis at defined levels of probability of $\mathrm{p}=0.05$, $\mathrm{p}=0.02, \mathrm{p}=0.01$ or $\mathrm{p}=0,001$.

\section{RESULTS}

It was found that $3 \%$ of all middle-school pupils from 20092011 experienced some form of contact with taking drugs. This rose to $11 \%$ in pupils from the older aged high-school group in 2011 (Fig. 1). Compared to 2009, however, the 2011 questionnaire had more specific questions focused on how often drugs were taken, for example, in the 30-day period prior to completing the questionnaire. It was found that of those taking drugs, $55 \%$ and $43 \%$, respectively, were middle and high-school pupils throughout this time.

For middle school pupils, there were twice as many boys taking psychoactive substances than girls. This relationship was further strengthened in high school pupils (Fig. 2).

The most commonly taken psychoactive substances by the pupils were marihuana and amphetamines. In the latter, 


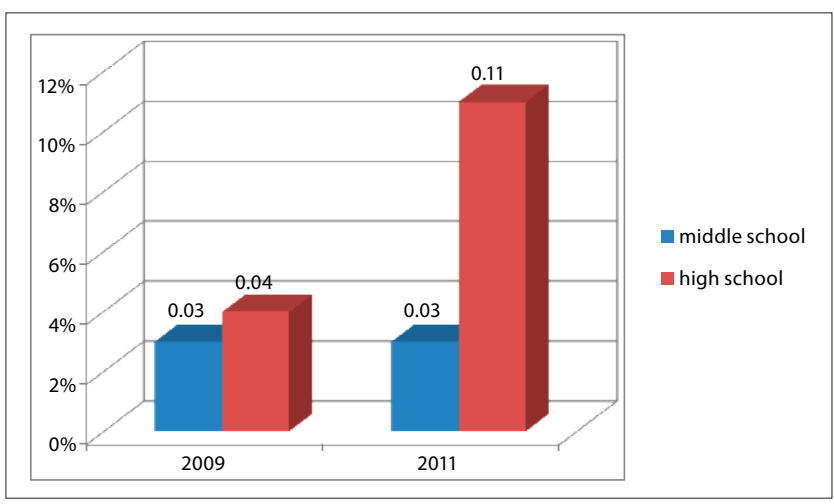

Figure 1. Proportions of pupils who ever took drugs in the years studied

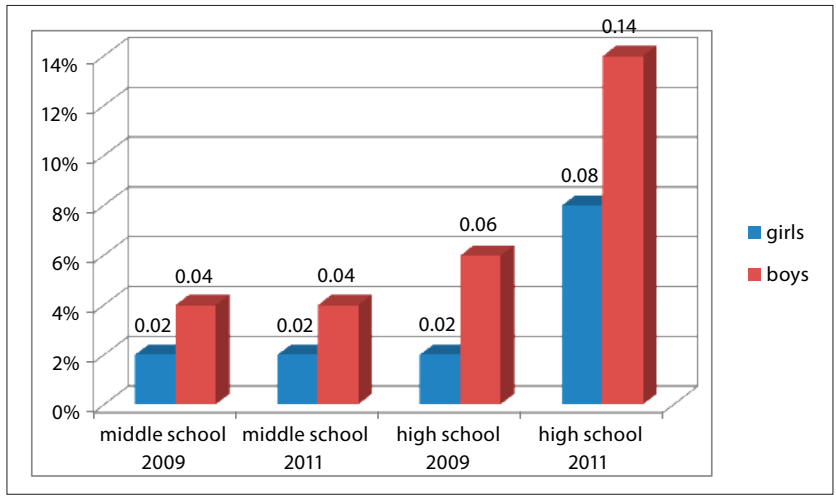

Figure 2. Proportions of pupils admitting to taking drugs, according to gender.

there were no significant differences noted in the incidence of use between the years studied. Despite a small decrease in marihuana use for 2011, this drug is undoubtedly still the most popularly used illegal drug by the studied teenagers (Tab. 1).

Table 1. Most frequently taken drugs by middle and high school pupils between 2009-2011

\begin{tabular}{lcccc}
\hline $\begin{array}{l}\text { Drug types taken } \\
\text { by adolescents }\end{array}$ & $\begin{array}{c}\text { Middle- } \\
\text { school pupils } \\
2009\end{array}$ & $\begin{array}{c}\text { Middle- } \\
\text { school pupils } \\
2011\end{array}$ & $\begin{array}{c}\text { High-school } \\
\text { pupils } \\
2009\end{array}$ & $\begin{array}{c}\text { High-school } \\
\text { pupils } \\
2011\end{array}$ \\
\hline marihuana & $62 \%$ & $51 \%$ & $80 \%$ & $69 \%$ \\
\hline amphetamines & $12 \%$ & $9 \%$ & $14 \%$ & $11 \%$ \\
\hline hashish & $4 \%$ & $6 \%$ & $9 \%$ & $12 \%$ \\
\hline heroin & $2 \%$ & $3 \%$ & $4 \%$ & $6 \%$ \\
\hline cocaine & $3 \%$ & $3 \%$ & $5 \%$ & $7 \%$ \\
\hline ecstasy & $3 \%$ & $4 \%$ & $9 \%$ & $7 \%$ \\
\hline medicinal drugs & $16 \%$ & $12 \%$ & $11 \%$ & $13 \%$ \\
\hline others & $27 \%$ & $24 \%$ & $14 \%$ & $19 \%$ \\
\hline P: $\left(\right.$ chi ${ }^{2}$ ) & $<0,001$ & $<0,001$ & $<0,001$ & $<0,001$ \\
\hline
\end{tabular}

As mentioned previously, the 2011 questionnaire was extended to include questions on how drugs were acquired; $34 \%$ and $39 \%$ middle and high-school pupils claimed that this was from friends, and somewhat fewer, respectively, $31 \%$ and $32 \%$, claiming from dealers. Both middle and highschool pupils (17\% and $19 \%$, respectively), replied that they gave their friends the money to purchase their drugs. These friends, however, may include persons with easy access to drugs or those who were unaware of the legal consequences of possessing such drugs.
The 2009 studies focused on parents as well as their offspring and, as such, had different questionnaires, designed to check the agreement between parents' and pupils' answers. In the case of psychoactive substances, none was found. Only $1 \%$ of parents claimed that their children took addictive psychoactive substances. It should noted that questions on drug taking can be sensitive, which should be allowed for when interpreting the results. Some information may have been withheld by both parents and/or pupils.

Without doubt, DDs constitute a type of alternative to established drugs. From the all-Poland 2011 study, it appears that there are, respectively, $3 \%$ and $4 \%$ of middle and high school pupils who had ever in their lives taken DDs. Of these, correspondingly $67 \%$ and $75 \%$ had taken DDs once or twice two months before the study. However, a very worrying feature is that, respectively, $18 \%$ and $11 \%$ took DDs more than 30 times during this period (Fig. 4). The most common types of DDs taken were: typhoon, concrete, shiva, buszek, black widow, rasta, bobi, gumijagody, magic, mohair.

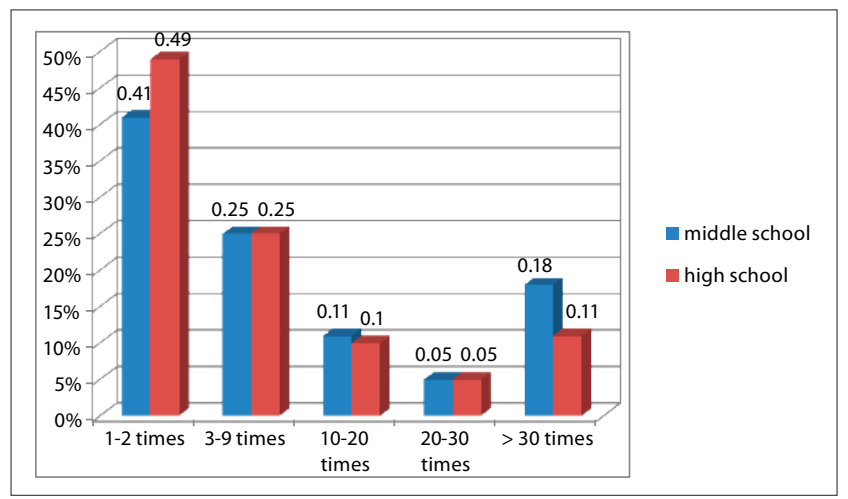

Figure 4. Incidence of taking DDs in adolescents two months prior to study

In both the younger and older age groups, the incidence of taking DDs was double in boys compared to girls (Fig. 5).

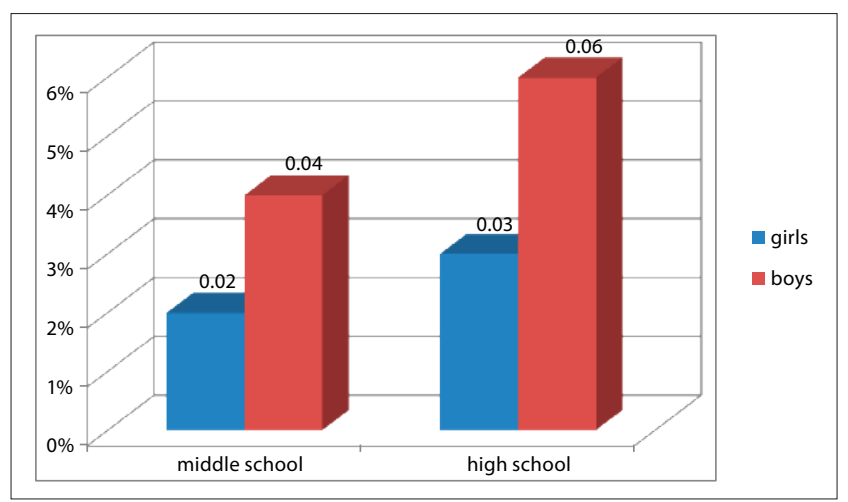

Figure 5. Proportions of adolescents taking Designer Drugs, according to gender.

The extended questionnaire from 2011 also included how DDs were acquired. Subjects most frequently bought these at 'Head Shops', from friends or dealers (Fig. 6).

Subjects showed that they indeed had knowledge of the adverse effects of taking drugs. There were practically no pupils (97\%) who did not realise the detrimental effects that taking drugs has on health. The all-Poland study of 2011, however, showed that $35 \%$ and $23 \%$, respectively, of middle and high-school pupils were unaware of the consequences of taking DDs. Such knowledge is sought on the Internet or 


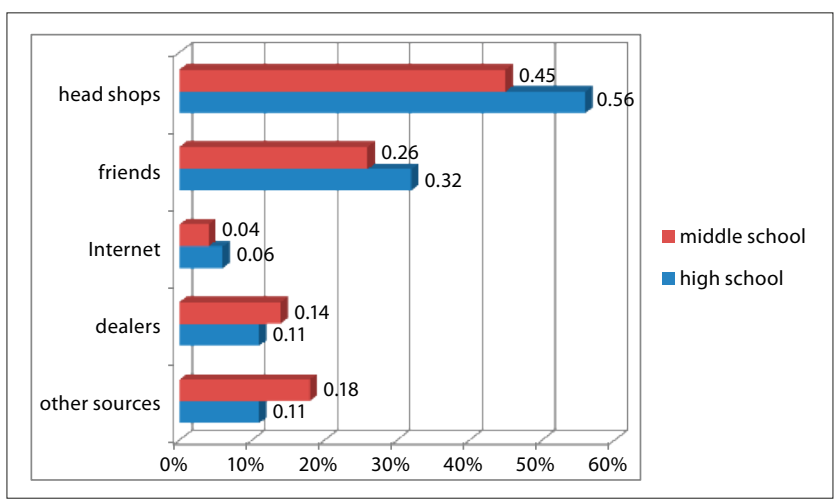

Figure 6. Sources from which Designer Drugs were obtained by middle and high-school pupils

obtained from their friends. Even though teenagers most frequently buy their DDs from Head-Shops, those selling them do not inform their customers of the health risks/ consequences when taking such drugs (Fig. 7).

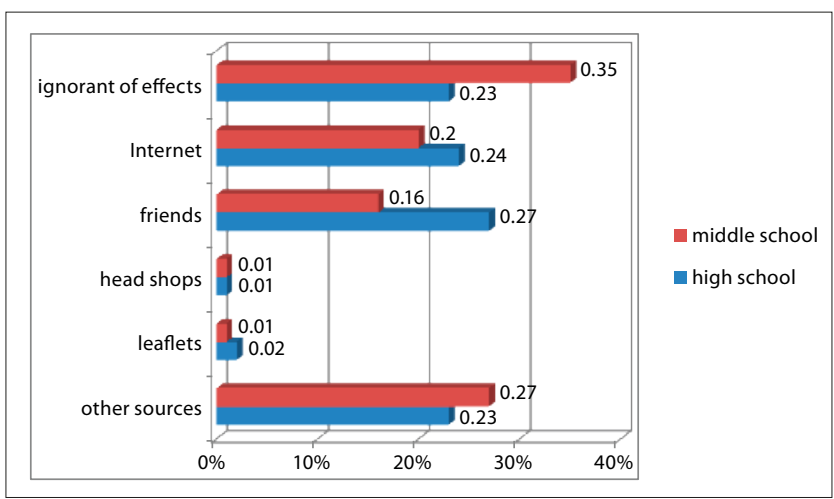

Figure 7. Ways in which adolescents acquire information about the consequences of taking Designer Drugs

Subjects most often described their taking of DDs as 'good fun', 'because I like to', 'because others do it' or 'something to kill the time'. Middle-school pupils more frequently stated that taking DDs helps them to cope better with their lives, which is important in potentiating an addiction (Table 2).

Table 2. Most frequent reasons given by adolescents for taking drugs or Designer Drugs

\begin{tabular}{lcccccc}
$\begin{array}{l}\text { Reasons given for taking } \\
\text { drugs and DDs by } \\
\text { adolescents }\end{array}$ & $\begin{array}{c}\text { Middle- } \\
\text { school } \\
\text { pupils } \\
2009\end{array}$ & $\begin{array}{c}\text { Middle-school } \\
\text { pupils } \\
2011\end{array}$ & $\begin{array}{c}\text { High- } \\
\text { school } \\
\text { pupils } \\
2009\end{array}$ & $\begin{array}{c}\text { High-school } \\
\text { pupils } \\
2011\end{array}$ \\
\cline { 2 - 7 } & Drugs & Drugs & DDs & Drugs & Drugs & DDs \\
\hline good fun & $10 \%$ & $12 \%$ & $21 \%$ & $27 \%$ & $35 \%$ & $15 \%$ \\
\hline Ilike to & $19 \%$ & $17 \%$ & $25 \%$ & $29 \%$ & $24 \%$ & $13 \%$ \\
\hline others do it & $14 \%$ & $18 \%$ & $14 \%$ & $12 \%$ & $11 \%$ & $10 \%$ \\
\hline to kill time & $12 \%$ & $19 \%$ & $10 \%$ & $7 \%$ & $9 \%$ & $14 \%$ \\
\hline improved coping with life & $7 \%$ & $16 \%$ & $9 \%$ & $4 \%$ & $8 \%$ & $8 \%$ \\
\hline I am addicted & $2 \%$ & $12 \%$ & $5 \%$ & $3 \%$ & $5 \%$ & $6 \%$ \\
\hline to catch up with friends & $2 \%$ & $6 \%$ & $5 \%$ & $1 \%$ & $4 \%$ & $2 \%$ \\
\hline other reasons & $27 \%$ & $15 \%$ & $14 \%$ & $18 \%$ & $11 \%$ & $32 \%$ \\
\hline P: (chi $\left.{ }^{2}\right)$ & $<0,001$ & $<0,001$ & $<0,001$ & $<0,001$ & $<0,001$ & $<0,001$ \\
\hline
\end{tabular}
by DDs as intoxicating substances on the market, lends itself to experimentation with these substances, not only by experienced persons but also with beginners [21].

Taking psychoactive substances for the first time brings about a pleasant experience, improving mood and even leading to a state of euphoria. The intensity of such experiences depends on the dose taken, how frequently they are used, tolerance, and the routes by which these substances are introduced into the body. An ever-present health threat exists regarding overdosing, mixing with alcohol and/or other recreational substances in order to enhance the desired effect. Such behaviour can arise from a lack of information on side-effects, medicinal drug/alcohol interactions, contraindications and knowing the effective dose. These effects can subconsciously often lead to becoming addicted, thereby requiring more drugs to satisfy this craving $[22,23]$. Teenagers frequently take psychoactive substances out of curiosity, for coping with life's difficulties, forgetting about 
daily chores, or to express rebellion against their immediate world. Psychoactive substances alter consciousness, give feelings of security and self-sufficiency. Adolescents can therefore create a different and improved reality for themselves, whilst losing control over their drug use as well as their bodies.

These behaviours can have serious health and societal consequences [24]. Psychoactive substances/drugs affect the Central Nervous System (CNS), resulting in psychomotor agitation, impaired consciousness and widespread body toxicity. In the case of DDs, their effects are not fully known in terms of the entire spectrum of impairments, disorders and complications arising from their use. Although ignorant of the risks, drug users may be become criminals in satisfying their addiction, along with progressing to stronger acting drugs. In this regard, it seems appropriate that education is the key: the dissemination of reliable information based on scientific evidence, epidemiology and any other bona-fide reporting on addictive substances is thus indicated [25].

Without doubt, peer pressure is also linked to drug or DD taking. The psychological need to initiate drug taking is increasingly apparent by individuals belonging to a peer group where this activity is commonplace. Teenagers are thus able to identify themselves in such peer groups, together with winning its approval. Furthermore, by these means teenagers can often acquire psychoactive substances from their friends. This is borne out by the 2011 study data where, respectively, $34 \%$ and $39 \%$ of middle and high-school pupils obtained drugs from their peers; the corresponding numbers for DDS being 26\% and 32\%. The all-Poland study also showed that peer acceptance is not the only incentive for adolescents taking drugs, but that they do so to increase their enjoyment and fun on a given occasion [26]. In such situations it goes without saying that the family should play a restraining/supervisory role. Having discussions with their children, together with participating in their development into adulthood, allows this difficult and vulnerable period of transition to be more fully monitored by parents. Moreover, relationships with parents are reinforced and suitable role models supported/promoted than had hitherto been adopted. Shortcomings in these areas lead to a weakening of emotional ties between parents and children. They can also be the cause of conflicts whereby children become disobedient to their parents. Through attracting attention to themselves or by expressing teenage rebellion, adolescents often start taking drugs [27].

The current study shows that according to the surveyed parents, only $1 \%$ of pupils took drugs. This is clearly a touchy subject for adults and indicates that they are unaware of the scale of the problem, or worse still, choose to wilfully ignore it. Risky high school adolescent behaviour, as demonstrated by addictive psychoactive substances abuse, requires the introduction of more effective programmes, activities and interventions promoting healthy lifestyle behaviour. It is also necessary that a more effective and integrated anti-drugs policy be adopted internationally, which includes reducing the supply and demand for these illegal substances.

The battle against drugs should ideally be directed against totally eliminating them from society, thereby removing their detrimental effects on human health. It is equally important to focus on prevention through having engaged and appropriately trained staff/specialists and to create suitable role-models for youth. Preparing an anti-DD strategy should take into consideration the various factors determining how effective any legislation can be in dealing with or modifying outcomes - the Public Health perspective being a key issue. It is vital to obtain the most reliable and accurate information possible on how DD substances act, their dosing toxicities, effects on physical and mental health, as well as on society. Such data can only be obtained by proper scientific studies conducted at centres of excellence. The need for scientific research is highlighted by the inconsistent and incomplete reporting on the harm caused by DDs, where different sources can provide conflicting data even for mortality and poisonings. Determining whether DDs probably or possibly are the direct cause of death or poisoning vitally depends on developing rapid methods for their identification and measurement that keep pace with changing circumstances. Users of DDs can thus avoid detection by routine monitoring if such analytical methods are not already in place.

Banning DDs should also be associated with preventative and educational measures. To this end, the Internet could be gainfully employed, given that $56 \%$ of Europe's population makes use of it and that it constitutes the main source of information on drugs for $61 \%$ of those aged $15-24$ years. However, neither government websites, online forums nor social networking sites are used as information sources for DDs [28-31]. The presented study illustrates this, where $20 \%$ and $24 \%$ of middle and high school pupils seek DD information from the Internet, as also confirmed by many other studies $[32,33]$. It so happens that Online forums can provide more accessible information for the average user with the added advantage of being interactive, thereby allowing for the exchanging of opinions, experiences, insights and knowledge, including scientific sources by which means interested parties are kept up-to-date with current data and news. The most comprehensive and up-to-date information on DDS, in fact, flow from users themselves. It is therefore necessary to develop a service which not only provides a reliable data base, but also allows rapid and efficient communication for those who require professional help and support. With this in mind, the UK has now established a website service 'Talktofrank' [34]. This not only consists of a compendium of knowledge about substances available, their potential user risk, popular slang terminology and legal status, but also permits fast contact with professionals for those, or those associated, who require help.

\section{CONCLUSIONS}

1. The taking of psychoactive substances is a universal phenomenon which in adolescents increases, particularly for both those of older age and for boys.

2. Even though DDs have only recently appeared on legal markets, they have become very popular among youths. As a result, further and more detailed scientific studies are necessary, together with constant monitoring of the DD situation.

3. Adolescents possess insufficient knowledge about DD use and their effects.

4. Family life has a big influence on whether a youth decides to experiment in taking drugs or DDs. Frequent and close relations with parents decreases the likelihood of drug taking. 
5. Drug taking is rated much lower by parents compared to their offspring. Deciding on remedial action is therefore required in this area.

6. Educational and preventative actions are highly justified due to the increasing threats to health and life in adolescents arising from the dynamically developing market available for psychoactive substances.

\section{REFERENCES}

1. World Drug Report 2012, UNODC, Nowy Jork 2012. https://www. unodc.org/documents/data-and analysis/WDR2012/WDR_2012_web_ small.pdf (accessed: 2014.04.07).

2. Sierosławski J. Studenci 2004. Raport $\mathrm{z}$ badania ankietowego na temat używania substancji psychoaktywnych przez studentów (Students 2004. Survey report on the use of psychoactive substances by students). http:// www.narkomania.org.pl/czytelnia/studenci-2004-raport-z-badaniaankietowego-na-temat-używania-substancji-psychoaktywnych (accessed: 2014.04.07) (in Polish).

3. Ustawa z dnia 29 lipca 2005 r. o przeciwdziałaniu narkomanii, Dziennik Ustaw z 2012 r. poz. 124, z późn. zm. (Act of 29 July 2005 amending the act on counteracting drug addiction, JL 2012 item. 124) (in Polish).

4. Pilling K. Hospital warning over „legal highs”. http://www.independent. co.uk/life-style/health-and-families/health-news/hospital-warningover-legal-high-2054889.html (accessed: 2014.04.07).

5. Brandt SD, Sumnall HR, Measham F, Cole J. Analyses of secondgeneration „legal highs” in the UK: The confusing case of NRG-1. Drug Test Anal 2010; 2(8) : 377-82.

6. Schmidt MM, Sharma A, Schifano F, Feinmann C. „Legal highs” on the net-evaluation of UK-based websites, products and product information. Forensic Sci Int. 2011; 206(1-3): 92-97.

7. Vardakou I, Pistos C, Spiliopoulou Ch. Spice drugs as a new trend: Mode of action, identification and legislation. Toxicol Lett. 2010; 197(3): 157-62.

8. Stan problemu narkotykowego w Europie (The state of the drugs problem in Europe). Sprawozdanie roczne 2008. EMCDDA, Urząd Oficjalnych Publikacji Wspólnot Europejskich, Luksemburg 2008. http://www. emcdda.europa.eu/system/files/publications/973/TDAC12001PLC_. pdf (accessed: 2014.04.07) (in Polish).

9. Eliott S, Smith C. Investigation of the first deaths in the United Kingdom involving the detection and quantitation of the piperazines BZP and 3-TFMP. J Anal Toxicol. 2008; 32(2): 172-77.

10. Wood DM, Dargan PI, Button J, Holt DW, Ovaska H, Ramsey J, et al. Collapse, reported seizure and an unexpected pill. Lancet 2007; 369(9571): 1490.

11. Biliński P, Hołownia P, Kapka-Skrzypczak L, Wojtyła A. Designer Drug (DD) abuse in Poland; a review of the psychoactive and toxic properties of substances found from seizures of illegal drug products and the legal consequences thereof. Part 1 - Cannabinoids and Cathinones. Ann Agric Environ Med. 2012; 19(4): 857-70.

12. Biliński P, Hołownia P, Kapka-Skrzypczak L, Wojtyła A. Designer Drug (DD) abuse in Poland; a review of the psychoactive and toxic properties of substances found from seizures of illegal drug products and the legal consequences thereof. Part II - Piperazines/Piperidines, Phenylethylamines, Tryptamines and miscellaneous 'Others. Ann Agric Environ Med. 2012; 19(4): 871-82.

13. Kapka-Skrzypczak L, Cyranka M, Wojtyła A. Legal highs as an urgent issue of public health. Pol J Public Health 2011(2): 174-80 (in Polish).

14. Kapka-Skrzypczak L, Kulpa P, Sawicki K, Cyranka M, Wojtyła A, Kruszewski M. Legal highs - legal aspects and legislative solutions. Ann Agric Environ Med. 2011; 18(2): 304-9.
15. Hughes B, Winstock AR. Controlling new drugs under marketing regulations. Addiction. 2012; 107(11): 1894-9.

16. Biliński P, Kapka-Skrzypczak L, Jabłoński P. Determining the scale of designer drugs (DD) abuse and risk to public health in Poland through an epidemiological study in adolescents. Ann Agric Environ Med. 2012; 19(3): 357-64.

17. The ESPAD Raport 2011. Alcohol and other drug use among students in 36 European Countries. http://www.espad.org/sites/espad.org/ files/The_2011_ESPAD_Report_FULL_2012_10_29.pdf (accessed: 2014.04.07)

18. Jabłoński P, Bukowska B, Malczewski A (ed.). Raport krajowy 2009: Sytuacja narkotykowa w Polsce, (2009 National Report: Narcotics Situation in Poland), Krajowe Biuro ds. Przeciwdziałania Narkomanii, Warsaw 2009 (in Polish).

19. Pawłowska B, Zygo M, Potembska E, Kapka-Skrzypczak L, Dreher P, Kędzierski Z. Psychoactive substances use experience and addiction or risk of addiction among by Polish adolescents living in rural and urban areas. Ann Agric Environ Med. 2014; 21(4): 776-82.

20. Hassen GW, Ghobadi F, Kalantari H. Synthetic drugs: a new trend and the hidden danger. Am J Emerg Med. 2013; 31(9): 1413-5.

21. Łukasik-Głębocka M, Sommerfeld K, Nawrocka K. Legal highs toxicitysymptomatology and clinical diagnosis in case series. Przegl Lek. 2010; 67(8): 613-16 (in Polish).

22. Jędrzejko M, Neroj A, Wojcieszek K, Kowalewska A. Teorie uzależnień od substancji psychoaktywnych (Theories of addiction to psychoactive substances). Współczesne teorie uzależnień od substancji psychoaktywnych (Contemporary theories of addiction to psychoactive substances). Jędrzejko M (red.) Akademia Humanistyczna im. A. Gieysztora-Oficyna Wydawnicza ASPRA-JR, Pułtusk-Warszawa 2009. p. 77-155 (in Polish).

23. Wojtyła-Buciora P, Wojtyła C, Urbaniak M, Kapka-Skrzypczak L, Wojtyła A, Diatczyk J, et al. Alcohol consumption in Polish middle and high school pupils-has this rapidly increased during 2009-11?. Ann Agric Environ Med. 2014; 21(3): 552-6.

24. Morawska-Siudak J, Szkolnicka B, Gomółka E, Krawczyk-Pasławska E. Designer drugs-diagnostic, psychological and low aspects of problem. Przegl Lek. 2010; 67(8): 598-601 (in Polish).

25. Biliński P, Wojtyła A, Kapka-Skrzypczak L, Chwedorowicz R, Cyranka M, Studziński T. Epigenetic regulation in drug addiction. Ann Agric Environ Med. 2012; 19(3): 491-6.

26. Kidawa M. Politoksykomania (Polytoxicomania). Remedium, 2008; 11: 28-29 (in Polish).

27. Warecki K. Dopalacze (Desiner drugs). Polskie Wydawnictwo Encyklopedyczne. Radom 2010 (in Polish).

28. Davies S, Wood DM, Smith G, Button J, Ramsey J, Archer R, et al. Purchasing "legal highs" on the Internet - is there consistency in what you get? QJM. 2010; 103(7): 489-93.

29. Zakrzewski T. Dopalacze w Internecie - marketing w służbie sprzedaży "środków zastępczych" w sieci (Boosters in Internet - marketing on sellservice "alternative means"). http://www.narkomania.org.pl/czytelnia/ dopalacze-w-internecie-marketing-w-sluzbie-sprzedazy-srodkowzastepczych-w-sieci/ (accessed: 2014.04.07) (in Polish).

30. Vardakou I, Pistos C, Spiliopoulou Ch. Drugs for youth via Internet and the example of mephedrone. Toxicol Lett. 2011; 201(3): 191-5.

31. Wood DM, Hunter L, Measham F, Dargan PI. Limited use of novel psychoactive substances in South London nightclubs. OJM. 2012; 105(10): 959-64.

32. Motyka M. Psychoactive substances among young people of secondary schools in Przemysl. Probl Hig Epidemiol. 2013; 94(2): 205-14 (in Polish).

33. Garus-Pakowska A, Drozdowska M, Moczulski R. Knowledge on psychoactive substances among students of selected Lodz universities. Part II. Probl Hig Epidemiol. 2012; 93(2): 356-62 (in Polish).

34. www.talktofrank.com/drugs-a-z (accessed: 2014.04.07). 